\title{
Effect of the nitrogen source on phycobiliprotein synthesis and cell reserves in a chromatically adapting filamentous cyanobacterium
}

\author{
Sylviane Liotenberg, Douglas Campbell, $\uparrow$ Rosmarie Rippka, \\ Jean Houmard and Nicole Tandeau de Marsac
}

Unité de Physiologie Microbienne, Département de Biochimie et Génétique Moléculaire, Institut Pasteur, 28 rue du Docteur Roux, 75724 Paris Cédex 15, France

\author{
Author for correspondence: Nicole Tandeau de Marsac. Tel: +3314568 8415. Fax: +33140613042. \\ e-mail: ntmarsac@pasteur.fr
}

Cyanobacteria can utilize nitrate or ammonium as a source of fixed nitrogen for cell growth. In the filamentous Calothrix sp. strain PCC 7601, these two sources of nitrogen differently influenced the phycobiliprotein composition of the phycobilisomes, the major light-harvesting antennae. When compared to nitrate, growth in the presence of ammonium resulted in intracellular steadystate levels $35 \%$ lower for phycoerythrin and $46 \%$ higher for phycocyanin. Besides these differences in cell pigmentation, a rapid but transient accumulation of cyanophycin granule polypeptide occurred in ammoniumgrown cells, while these macromolecules were not detected in cells grown with nitrate. In contrast, glycogen reserves displayed a dynamic pattern of accumulation and disappearance during cell growth which varied only slightly with the nitrogen source. The observed changes in cell pigmentation are reminiscent of the phenomenon of complementary chromatic adaptation, in which green and red wavelengths promote the syntheses of phycoerythrin and phycocyanin-2, respectively. As in complementary chromatic adaptation, the regulation of synthesis of phycoerythrin and phycocyanin-2 by the nitrogen source occurred mainly at the mRNA level. Moreover, the transcriptional start sites for the expression of the cpeBA and the cpc2 operons, which respectively encode the two subunits of phycoerythrin and phycocyanin-2, were the same in cells grown in nitrate or ammonium, and identical to those in green- and red-light-grown cells. The results of this study suggest that acclimation to the spectral light quality and to the nitrogen source share some common regulatory elements.

Keywords: Calothrix sp. PCC 7601, light-harvesting antennae, nitrogen assimilation, cyanophycin, glycogen

\section{INTRODUCTION}

Cyanobacteria constitute a large and very diverse group of prokaryotic organisms performing oxygenic photosynthesis. Their photosynthetic apparatus is similar to that of plants except that light is harvested mainly by phycobiliproteins. These chromoproteins are organized into stable multimolecular structures, called phycobilisomes,

†Present address: Department of Plant Physiology, University of Umeå, S-90187 Umeá, Sweden.

Abbreviations: $A P$, allophycocyanin; $P C$, phycocyanin; $P E$, phycoerythrin; KU, Klett units; PPFD, photosynthetic photon flux density. that are attached to the stromal surface of the thylakoid membranes. Phycobilisomes are composed of two domains: the central core proximal to the photosynthetic membrane, and six rods which radiate from the core. In Calothrix PCC 7601 the phycobilisome contains the bluecoloured phycobiliproteins allophycocyanin (AP) and phycocyanin (PC), and the pink-coloured phycoerythrin (PE). AP is located in the core substructure of the phycobilisome, while PC and PE form the peripheral rods (Bryant, 1987, 1991; Glazer, 1989; Grossman et al., 1993).

The cyanobacteria have developed unique physiological and morphological features to respond to changes in environmental parameters, such as light and nutrients, 
which allow them collectively to colonize nearly all ecosystems (Tandeau de Marsac \& Houmard, 1993). For example, cells of Calotbrix PCC 7601 can adjust their phycobiliprotein content to the wavelengths of the incident light available during growth. This phenomenon, called complementary chromatic adaptation, is characterized by a preferential synthesis of light-harvesting pigments with absorption spectra complementary to the incident light wavelengths, PE under green light and phycocyanin-2 (PC-2) under red light. In contrast, AP and phycocyanin-1 (PC-1) are synthesized independently of the spectral light quality (Tandeau de Marsac \& Houmard, 1993). The interactions between the regulation of photosynthesis and nitrogen metabolism have received limited investigation in cyanobacteria. Nitrate reduction is known, however, to be a genuine photosynthetic process, which directly uses photosynthetically generated reductant (Guerrero \& Lara, 1987).

Cyanobacteria can generally use nitrate, nitrite and ammonium as sole nitrogen sources for growth (Guerrero \& Lara, 1987; Flores \& Herrero, 1994). Some strains may reduce molecular nitrogen and grow at the expense of the ammonium that results from this process (Fay, 1992). When externally supplied, ammonium ions $\left(\mathrm{NH}_{4}^{+}\right)$enter the cells via an active transport system, while the unprotonated form $\left(\mathrm{NH}_{3}\right)$ enters by diffusion and is trapped by protonation. Nitrate is taken up by cyanobacterial cells via an active transport system and is sequentially reduced to nitrite by nitrate reductase and then to ammonium by nitrite reductase. The glutamine synthetase (GS)-glutamate synthase (GOGAT) enzyme system is quantitatively the most important pathway for the assimilation of ammonium, either exogenously supplied or internally generated. As all nitrogen sources converge to the production of ammonium and glutamine, any physiological differences related to nitrogen sources must be due to the level of ammonium within the cell or to a direct effect of the nitrogen source on the regulation of cell metabolism.

Cyanobacteria accumulate different types of reserves that can be used as a source of either nitrogen, carbon, or both (Allen, 1984). Cyanophycin is a nitrogen reserve unique to, but not universally present in, cyanobacteria (Simon, 1973a, b; Allen \& Hutchison, 1980; Lawry \& Simon, 1982). These non-ribosomally synthesized polypeptides consist of equimolar quantities of arginine and aspartic acid that further assemble into granules of molecular mass ranging from 25000 to $100000 \mathrm{kDa}$ (Simon, 1971, 1973a, 1976). Cyanophycin usually accumulates in cells growing with a nitrogen supply in excess of other essential nutrients, such as phosphorus and sulphur, but decreases under nitrogen-deficient growth conditions, where it serves as a nitrogen source (Allen et al., 1980; Simon, 1973b). According to Carr (1988), cyanophycin granule polypeptides are a more dynamic nitrogen reserve than phycobiliproteins.

Glycogen is the major carbon and energy reserve compound accumulated by cyanobacteria during photoautotrophic growth (Smith, 1982). Accumulation of this glucose polymer can occur as a result of nitrogen-limited growth conditions in the light or in the presence of an excess of utilizable carbon source (Lehmann \& Wöber, 1976; Allen \& Smith, 1969). Growth under suboptimal temperature conditions (van Eykelenburg, 1980), or a sudden increase in light energy input without changes in nitrogen metabolism, may also lead to glycogen accumulation (Ernst \& Böger, 1985). In the dark or in the light, once conditions for balanced growth are reestablished, glycogen reserves are rapidly degraded to yield energy and carbon for cell metabolism. Glycogen may therefore act as a reserve with dual functions of storage product and buffer substance between carbon fixation and carbon consumption in other biosynthetic pathways (Carr, 1988).

Phycobiliprotein synthesis depends on the supply of assimilable nitrogen in the environment, and these proteins may serve as a nitrogen reserve (Tandeau de Marsac \& Houmard, 1993). Cyanobacteria incapable of fixing molecular nitrogen respond to nitrogen deprivation by degrading the phycobiliproteins and linker polypeptides that form the phycobilisomes, leading to a rapid cell bleaching (Allen, 1984; Bryant, 1987, 1991; Collier \& Grossman, 1992, 1994). As originally postulated by Allen \& Smith (1969) for Anacystis nidulans (Synechococcus sp. PCC 6301), phycocyanin acts as a nitrogen storage compound in Spirulina platensis (Boussiba \& Richmond, 1980). In the marine cyanobacterium Synechococcus sp. strain DC2, free phycoerythrin is also a pool of stored nitrogen (Wyman et al., 1985), of importance in marine environments, where nitrogen is frequently limiting.

The filamentous cyanobacterium Calotbrix PCC 7601 has lost the capacity to differentiate functional heterocysts and to fix dinitrogen (Kallas et al., 1985); combined nitrogen must therefore be provided for cell growth. To study the regulatory mechanism linking nitrogen assimilation and photosynthesis, we have examined the effect of the nature of the nitrogen source (nitrate or ammonium) on the synthesis of the phycobiliproteins, and on the accumulation of cellular nitrogen and carbon reserves in this chromatically adapting cyanobacterium.

\section{METHODS}

Organism and growth conditions. The filamentous cyanobacterium Calotbrix sp. strain PCC 7601 (= Fremyella diplosiphon UTEX 481; hereafter designated Calothrix PCC 7601) was grown at $27^{\circ} \mathrm{C}$ in Erlenmeyer flasks (1 l) containing $500 \mathrm{ml}$ liquid BG-11 medium (Rippka et al., 1979) buffered with filtersterilized $10 \mathrm{mM} \mathrm{NaHCO}_{3}$ and $10 \mathrm{mM}$ HEPES/ $\mathrm{NaOH}, \mathrm{pH} 8 \cdot 0$. When ammonium was used as a nitrogen source, $\mathrm{NaNO}_{3}$ was replaced by $5 \mathrm{mM} \mathrm{NH}_{4} \mathrm{Cl}$. Cultures were agitated with magnetic stirring bars and continuously gassed with air $/ \mathrm{CO}_{2}(99: 1, \mathrm{v} / \mathrm{v})$. White light was supplied by fluorescent lamps (OSRAM L18W/25 Universal White) providing a photosynthetic photon flux density (PPFD) of $50 \mu \mathrm{mol} \mathrm{m} \mathrm{m}^{-2} \mathrm{~s}^{-1}$ measured with a LICOR LI-185B quantum/radiometer/photometer equipped with a LI-190SB quantum sensor. Growth was followed by measuring Klett units (KU) with a Klett Summerson colorimeter, model 800-3, equipped with a red filter no. 66 transmitting light between 640 and $700 \mathrm{~nm}$. 
For the different experiments, a stock culture of nitrate-grown cells that had reached $200 \mathrm{KU}$ was diluted to an initial cell density of $15 \mathrm{KU}$ in fresh culture medium. These precultures contained either $17.6 \mathrm{mM} \mathrm{NaNO}_{3}$ or $5 \mathrm{mM} \mathrm{NH}_{4} \mathrm{Cl}$ as a nitrogen source. After $26 \mathrm{~h}$, these actively growing precultures, which had reached approximately $100 \mathrm{KU}$, corresponding to an $\mathrm{OD}_{750}$ of $0.5-0.6$, were diluted $1: 6$ in fresh medium of identical composition, generating the experimental cultures from which samples were collected at different times during cell growth. For all the parameters presented in this paper, values given at time 0 correspond to those determined on samples of the precultures collected at $26 \mathrm{~h}$. Aliquots of the same cell suspensions were immediately used to inoculate the experimental cultures. The purity of the cultures was checked at each step as described by Rippka et al. (1979). As Calotbrix PCC 7601 cells are rather sensitive to lysis when culture conditions are changed, the above experimental strategy was chosen as the least stressful treatment. It provided cells in a very reproducible physiological state to start the experimental cultures. Like some other cyanobacteria, Calotbrix PCC 7601 cells do not take up nitrate when ammonium is available as a nitrogen source (Martín-Nieto et al., 1989). The nitrate concentration of $0.08 \mathrm{mM}$ (determined by using the kit from Boehringer Mannheim, ref. 90565) at the onset of the experimental cultures containing ammonium remained constant until the end of the experiments. Therefore any effect of nitrate on the results could be excluded.

Preparation of crude cell-free extracts. Cell samples from both culture conditions described above, corresponding to approximately $50 \mu \mathrm{g}$ chlorophyll $a$, were harvested by centrifugation $\left(15 \mathrm{~min}, 8000 \mathrm{~g}, 20^{\circ} \mathrm{C}\right)$. The pellets were washed twice with $20 \mathrm{mM}$ sodium acetate buffer, $\mathrm{pH} 5.5$, containing $10 \mathrm{mM}$ $\mathrm{Na}_{2}$ EDTA and $500 \mu \mathrm{M}$ Pefabloc (Pentapharm AG), as protease inhibitors, and stored at $-20^{\circ} \mathrm{C}$ until analysis. Each pellet was resuspended to a final volume of $3.7 \mathrm{ml}$ in the same buffer. The thawed cell suspension was then subjected to two passages through a mini French pressure cell at $135 \mathrm{MPa}$. Complete cell breakage was confirmed by microscopic examination of the crude extract.

Phycobiliprotein determination. Crude cell-free extract $(1.9 \mathrm{ml})$ was precipitated with $100 \mu \mathrm{l}$ of a $200 \mathrm{mg} \mathrm{ml}^{-1}$ streptomycin sulphate solution for $30 \mathrm{~min}$ at $4{ }^{\circ} \mathrm{C}$ and centrifuged at $18000 \mathrm{~g}$ for $10 \mathrm{~min}$ at $4{ }^{\circ} \mathrm{C}$, in order to eliminate membrane fragments containing chlorophyll $a$ (Tandeau de Marsac \& Houmard, 1988). The supernatant was supplemented with $1 \mathrm{mM}$ dithiothreitol. The amounts of PE, PC and AP were calculated from measurements of the absorbances at 565, 620 and $650 \mathrm{~nm}$ as previously described (Tandeau de Marsac \& Houmard, 1988). These measurements do not distinguish between the constitutive PC-1 and the inducible PC-2, which differ only slightly spectroscopically (Bryant \& Cohen-Bazire, 1981).

Chlorophyll a determination. Crude cell-free extract $(0.5 \mathrm{ml})$ was extracted with $90 \%(\mathrm{v} / \mathrm{v})$ methanol for $1 \mathrm{~h}$ at $4{ }^{\circ} \mathrm{C}$ in dim light, followed by centrifugation at $10000 \mathrm{~g}$ for $15 \mathrm{~min}$ at $4^{\circ} \mathrm{C}$. The chlorophyll $a$ content was calculated from the absorbance of the methanolic extract at $665 \mathrm{~nm}$ (Tandeau de Marsac \& Houmard, 1988).

Protein determination. The proteih content of crude cell-free extracts $(1 \mathrm{ml})$ was determined by the Lowry method, with bovine serum albumin as standard, as described by Tandeau de Marsac \& Houmard (1988). The Lowry method does not detect cyanophycin granule polypeptide, composed of polymers of arginine and aspartate.
Extraction and determination of cyanophycin granule polypeptide. Samples were prepared as described for crude cell-free extracts except that cell pellets were washed with sterile distilled $\mathrm{H}_{2} \mathrm{O}$. Cell samples for cyanophycin detection corresponded to approximately $50-80 \mu \mathrm{g}$ chlorophyll $a$ for ammonium-grown cultures. The lack of cyanophycin in nitrate-grown cultures was confirmed on larger volumes, corresponding to as much as $200 \mu \mathrm{g}$ chlorophyll $a$. Cyanophycin granules were isolated from crude cell-free extracts and their arginine content was measured by the modified Sakaguchi reaction as described by Simon (1973b). The arginine content was then converted to cyanophycin granule polypeptide as described by Allen \& Weathers (1980). Values represent the means of two determinations on duplicate samples treated independently.

Glycogen determination. Cell suspensions, corresponding to 7-15 $\mu \mathrm{g}$ chlorophyll $a$, were concentrated to $1 \mathrm{ml}$ by centrifugation $\left(15 \mathrm{~min}, 8000 \mathrm{~g}, 20^{\circ} \mathrm{C}\right)$ and stored at $-20^{\circ} \mathrm{C}$ until analysis. Samples $(200 \mu \mathrm{l})$ were hydrolysed by boiling for $20 \mathrm{~min}$ with $10 \mu \mathrm{l} 50 \%(\mathrm{v} / \mathrm{v}) \mathrm{H}_{2} \mathrm{SO}_{4}$. One millilitre of o-toluidine reagent (Sigma, ref. 635-6) was then added. Samples were boiled for $10 \mathrm{~min}$, cooled on ice, and the concentration of glucose released by the acid hydrolysis was calculated from the absorbance at $635 \mathrm{~nm}$ using a standard curve established with a glucose solution (Sigma, ref. 635-100). Values represent the means of two determinations made on samples from two or three independent cultures.

Dry weight determination. Cell suspensions, corresponding to approximately $70 \mu \mathrm{g}$ chlorophyll $a$, were harvested by centrifugation $\left(15 \mathrm{~min}, 27000 \mathrm{~g}, 20^{\circ} \mathrm{C}\right)$. Cell pellets were washed twice and resuspended in $20 \mathrm{ml}$ sterile distilled $\mathrm{H}_{2} \mathrm{O}$. Cell suspensions were then divided into three aliquots which were harvested by centrifugation, washed once and resuspended in a minimal volume of sterile distilled $\mathrm{H}_{2} \mathrm{O}$. These samples were dried in aluminium cups at $60^{\circ} \mathrm{C}$ for at least $3 \mathrm{~d}$, to permit complete liquid evaporation before weighing.

Ammonium determination. The concentration of ammonium in the culture medium was determined by adding $50 \mu \mathrm{l}$ Nessler reagent (Sigma, ref. 14-2) to $1 \mathrm{ml}$ of samples which were appropriately diluted with fresh BG-11 0 culture medium devoid of ammonium chloride (Rippka et al., 1979). The absorbance at $395 \mathrm{~nm}$ was immediately determined and ammonium concentration was calculated by reference to a standard curve of 30-200 $\mu \mathrm{M}$ ammonium chioride in medium BG-11 0 . Values represent the means of three to six determinations made on samples from two independent cultures.

RNA preparation, hybridization with ${ }^{32} \mathrm{P}$-labelled probes, and primer extension. Cell suspensions corresponding to approximately $200 \mu \mathrm{g}$ chlorophyll $a$ were harvested by filtration through Millipore filters $(8 \mu \mathrm{m}$ pore size). Cells were resuspended in $650 \mu \mathrm{l}$ cold buffer $(10 \mathrm{mM}$ sodium acetate $\mathrm{pH} 4.5,200 \mathrm{mM}$ sucrose, $55 \mathrm{mM} \mathrm{Na}_{2}$ EDTA). After addition of $1 \mathrm{~g}$ sterile glass beads $(0.11 \mathrm{~mm}$ diameter, Braun), the cell samples were frozen in liquid nitrogen and kept at $-20^{\circ} \mathrm{C}$ until analysis. Total RNA was prepared by the procedure described by Mazel et al. (1986) with the following modifications: $0.3 \mathrm{ml}$ of $3 \%(\mathrm{w} / \mathrm{v})$ Bentone MA (previously called Macaloid; Rheox Company, NL Industries, PO Box 700 Highstown, NJ 08520, USA) in 0.1 M Tris $/ \mathrm{HCl}, \mathrm{pH} 8 \cdot 0,70 \mu \mathrm{l}$ of $20 \%$ (w/v) sodium dodecyl sulphate and $1.5 \mathrm{ml}$ of phenol [saturated with $100 \mathrm{mM}$ Tris/ $\mathrm{HCl}, 1 \mathrm{mM}$ $\mathrm{Na}_{2}$ EDTA, $\mathrm{pH} 8 \cdot 0$, and containing $0.1 \%$ (w/v) 8-hydroxyquinoline] were added to the frozen samples. Cell disruption was achieved by eight pulses of $30 \mathrm{~s}$ of vortexing at maximal speed, with an interval of $30 \mathrm{~s}$ between each pulse to prevent heating. Cell extracts were then centrifuged at $8000 \mathrm{~g}$ for $15 \mathrm{~min}$ 
at $4{ }^{\circ} \mathrm{C}$. The aqueous phases were collected, adjusted to $1 \mathrm{M}$ with $\mathrm{NaCl}$, and total RNA precipitated with 2 vols cold ethanol for $2 \mathrm{~h}$ at $-20^{\circ} \mathrm{C}$. After centrifugation at $12000 \mathrm{~g}$ for $30 \mathrm{~min}$ at $4{ }^{\circ} \mathrm{C}$, each pellet was resuspended in $100 \mu \mathrm{H}_{2} \mathrm{O}$ and RNA was again precipitated with cold ethanol in the presence of $0.3 \mathrm{M}$ sodium acetate $\mathrm{pH} 5 \cdot 2$. Each RNA sample, containing approximately $100-150 \mu \mathrm{g}$ total RNA, as determined by absorbance at $260 \mathrm{~nm}$, was resuspended in $\mathrm{H}_{2} \mathrm{O}$ to a final concentration of $2 \mu \mathrm{gl}^{-1}$. Aliquots were kept at $-70^{\circ} \mathrm{C}$ until use. Sterile distilled $\mathrm{H}_{2} \mathrm{O}$ treated with DEPC (diethylpyrocarbonate) was used throughout the procedure described above.

Samples containing $12 \mu \mathrm{g}$ total RNA per lane were electrophoresed for $16-18 \mathrm{~h}$ at $1.6 \mathrm{~V} \mathrm{~cm}^{-1}$ through $1.6 \%(\mathrm{w} / \mathrm{v})$ agarose gels. Both the gel and the running buffers contained $0.05 \mathrm{M}$

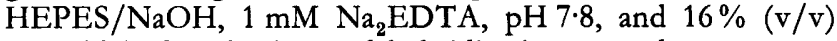
formaldehyde. Blotting and hybridization procedures were as described by Campbell et al., (1993). The DNA probes were as follows: AP, a $1.1 \mathrm{~kb}$ DraI fragment encoding AP subunits $\alpha$ and $\beta$ (apcA1B1) (Houmard et al., 1988); PC-2, a $0.4 \mathrm{~kb} S s p \mathrm{I}$ fragment located just upstream from the ATG codon and carrying the transcribed but untranslated region of the $c p c 2$ operon (cpcB2A2H2I2D2) (Tandeau de Marsac et al., 1988); $\mathrm{PE}$, a $1 \cdot 1 \mathrm{~kb} X b a \mathrm{I}-E c o \mathrm{RI}$ fragment encoding part of the $\beta$ and $\alpha$ PE subunits ( $c p e B$ and $c p e A$ ) (Mazel et al., 1986); PC-1, a $0.36 \mathrm{~kb}$ HindIII fragment of pPM114 carrying part of the $c p c 1$ promoter and the beginning of the $\beta$ subunit of PC-1 (Schyns et al., 1994). To quantify the relative transcript levels, the radioactivity of the hybridizing bands on the RNA blots was determined by scanning photoactivable screens on a Molecular Dynamics 445SI PhosphorImager. All quantifications, data display and analysis were performed using Molecular Dynamics Image Quant software. A 120 bp XcmI-PvuI restriction fragment internal to the Calotbrix PCC 7601 rnpB gene encoding the RNA subunit of ribonuclease $\mathrm{P}$ (Vioque, 1992) was used as a probe to quantify the amount of RNA loaded and transferred to the filters, and to standardize the measurements. The steady-state levels of the $r n p B$ transcripts from ammonium- and nitrategrown cells correlated well with the abundance of total rRNAs as visualized on agarose gels after staining with ethidium bromide.

For primer extensions, $20 \mu \mathrm{g}$ total RNA was precipitated with $10^{6}$ c.p.m. of radioactively end-labelled primers and the reactions were performed as described by Golden et al. (1986) except that annealings between RNAs and primers were performed at $37^{\circ} \mathrm{C}$ for $16 \mathrm{~h}$. AMV reverse transcriptase (Boehringer) was used in a PXII buffer from which $\mathrm{KCl}$ was omitted. The oligonucleotides used as primers were: 5'GCATCTGCTGAAACTACAGC-3', complementary to part of the nucleotide sequence downstream from the initiation codon of the $c$ peB gene (Fig. 5b), and 5'-GCCTCTAGTATCAGCCTGGG-3' and 5'-CAAT'TCCCT'TGGCAATCAGG$3^{\prime}$, complementary to parts of the nucleotide sequences located downstream and upstream, respectively, from the initiation codon of the $c p c B 2$ gene (Fig. 5b).

\section{RESULTS}

\section{Growth in the presence of nitrate or ammonium}

Several growth parameters were measured in order to identify quasi-steady-state conditions under which to compare the physiological states of growth arising from different nitrogen sources. Cyanobacteria are often susceptible to ammonium poisoning under suboptimal growth conditions (Abeliovitch \& Azov, 1976; Boussiba \& Gibson, 1991) and $\mathrm{NaHCO}_{3}$ is necessary for am-

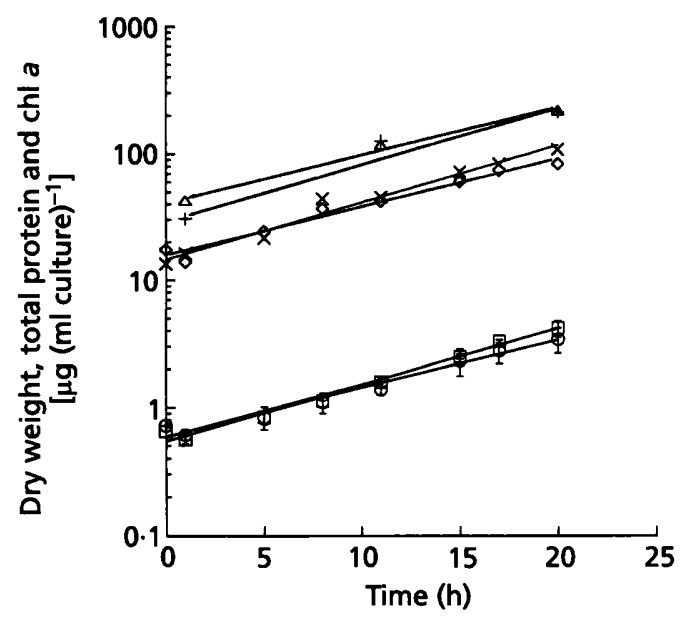

Fig. 1. Effect of the source of fixed nitrogen on growth of Calothrix PCC 7601 cells, measured as dry weight $(+$, nitrategrown cells; $\triangle$, ammonium-grown cells), total cell protein ( $\diamond$, nitrate-grown cells; $X$, ammonium-grown cells) and chlorophyll a (chl a) (O, nitrate-grown cells; $\square$, ammonium-grown cells). Error bars represent \pm SD of three independent replicates. Values for dry weight and total cell protein are the means of three determinations on the same culture.

monium uptake (Boussiba et al., 1984). Therefore, the culture medium was supplemented with $\mathrm{NaHCO}_{3}$ and HEPES to maintain the $\mathrm{pH}$ between 7.5 and 7.8 during growth. Under these conditions, ammonium chloride at $5 \mathrm{mM}$ permitted good growth of Calotbrix PCC 7601. Preliminary experiments showed that oxygen evolution was similar in nitrate- and ammonium-grown cells when measured under a PPFD of $50 \mu \mathrm{mol} \mathrm{m}^{-2} \mathrm{~s}^{-1}$ supplied by an incandescent lamp, indicating that ammonium at that concentration did not uncouple linear electron transport (data not shown).

To perform the experiments described in this paper, a stock culture grown in nitrate was diluted and grown as a preculture in the nitrogen source of choice (nitrate or ammonium) for $26 \mathrm{~h}$, followed by a second dilution to form the experimental culture, from which measurements were derived (see Methods for details). Doubling times, based on dry weight, total cell protein or chlorophyll $a$ content, were $6-7 \mathrm{~h}$ for the cultures grown with either ammonium or nitrate as the source of fixed nitrogen (Fig. 1). Growth proceeded exponentially for at least $20 \mathrm{~h}$ after the dilution of the cultures. We thus chose for this study to measure all parameters during this period of stability and to express results on a chlorophyll $a$ basis.

\section{Influence of the nitrogen source on the phycobiliprotein content}

Preliminary experiments showed that Calothrix PCC 7601 cells grown under white light and in the presence of nitrate were brown-red in colour. If such nitrogen-replete cells were transferred to a medium containing ammonium, they became greenish within less than two generations. 

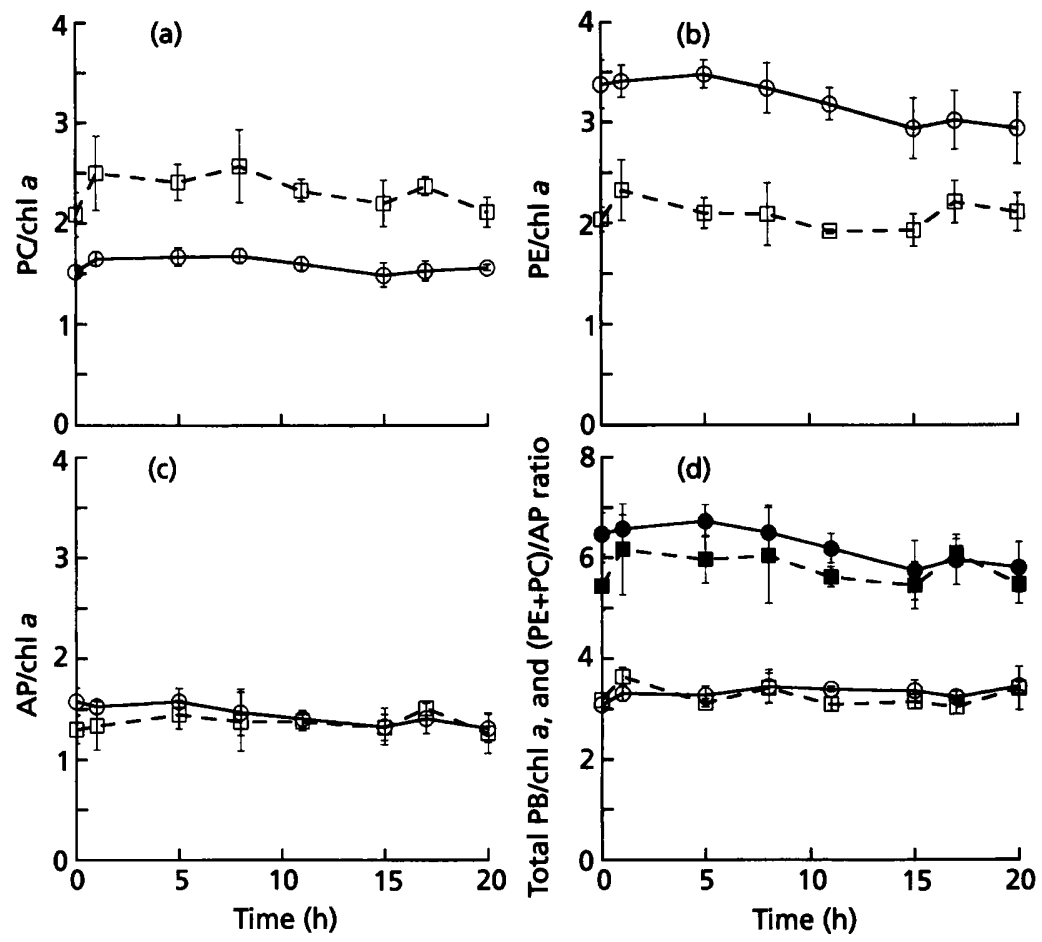

Fig. 2. Effect of the source of fixed nitrogen on the phycobiliprotein content of Calothrix PCC 7601 cells. (a, b, c) Phycocyanin (PC), phycoerythin (PE) and allophycocyanin (AP), respectively, from cultures grown in the presence of nitrate (-O-) or ammonium $(---\square---)$, expressed as $\mu \mathrm{g}$ phycobiliprotein (PB) per $\mu \mathrm{g}$ chlorophyll a (chl a). (d) Total PB from nitrate- (-O) or ammonium-grown cells (--- ---$)$, expressed as $\mu \mathrm{g}$ PB per $\mu \mathrm{g} \mathrm{chl}$ $a$, and $(P E+P C) / A P$ ratios from nitrate$(-\mathrm{O}-)$ or ammonium-grown cells (--- $\square---)$. Error bars represent \pm SD of three independent replicates.
After reaching stationary phase, cells recovered a slightly brown-reddish colour, but upon dilution to a fresh medium containing ammonium they again displayed a similar cycle of changes in pigmentation. When exponentially growing in a medium containing both nitrate and ammonium, cells exhibited the same greenish phenotype as with ammonium alone. Similarly, cells that had experienced $12 \mathrm{~h}$ of nitrogen starvation became green or brown-red after addition of ammonium or nitrate, respectively (data not shown).

In order to examine the synthesis of phycobiliproteins during steady-state growth on nitrate as compared to ammonium, cells were incubated in the presence of either nitrogen source, and the pigment content of the cells was determined on samples removed at different times (Fig. $2 a-d)$. The AP content of cells grown in the presence of either nitrate or ammonium did not differ significantly, since the AP/chlorophyll $a$ ratio remained approximately 1.5 under both growth conditions (Fig. 2c). In contrast, the nitrogen source markedly influenced the PE and PC content of the cells. PE was $35 \%$ lower in ammoniumcompared to nitrate-grown cells (Fig. $2 b$ ), whereas PC was $46 \%$ higher (Fig. $2 a$ ). In ammonium-grown cells the $\mathrm{PE} / \mathrm{PC}$ ratio was about 1 , indicating that the phycobilisomes contain the same number of PE and PC discs, whereas this ratio was about twofold higher in nitrategrown cells (compare Figs $2 a$ and $2 b$ ). The ratios of total phycobiliproteins to chlorophyll $a$, and of PE + PC to AP, which are proportional to the number of phycobilisomes per unit photosynthetic membrane and the number of peripheral discs per phycobilisome, respectively, remained unchanged whatever the source of nitrogen (Fig. 2d).
These results indicate that the nitrogen source specifically modulates the composition of the phycobilisome rods, but neither their length nor the total number of phycobilisomes per unit photosynthetic membrane.

\section{Accumulation of cyanophycin and glycogen reserves}

No cyanophycin granules were visible by light microscopy in nitrate-grown cells of Calothrix PCC 7601, at any phase of growth examined. In contrast, a preculture incubated in an ammonium-containing medium exhibited, upon transfer to experimental culture conditions, a transient accumulation of these structured granules, which appeared dispersed throughout the cytoplasm. A rapid accumulation of cyanophycin granule polypeptide occurred over the first $5 \mathrm{~h}$ (Fig. 3a). Subsequently, the specific rate of synthesis decreased and finally ceased, resulting at $20 \mathrm{~h}$ in the same specific content of this polypeptide as that observed at $1 \mathrm{~h}$ (Fig. 3a). At $11 \mathrm{~h}$ after transfer, the amount of cyanophycin granule polypeptide corresponded to approximately $5 \%$ of the cell dry weight. The accumulation of cyanophycin granules occurred in parallel with an initial consumption of ammonium from the culture medium that was significantly higher than that observed during subsequent growth (Fig. 3a). After $26 \mathrm{~h}$ (corresponding to a culture density of $100 \mathrm{KU}$ ) of growth in the presence of ammonium, cells were in late exponential phase and no longer contained any cyanophycin granules, although the culture medium still contained $2 \mathrm{mM}$ ammonium (data not shown).

The glycogen content of nitrate- and ammonium-grown cells was measured in the same time-course experiment (Fig. 3b). Upon dilution of the culture, cells exhibited a 

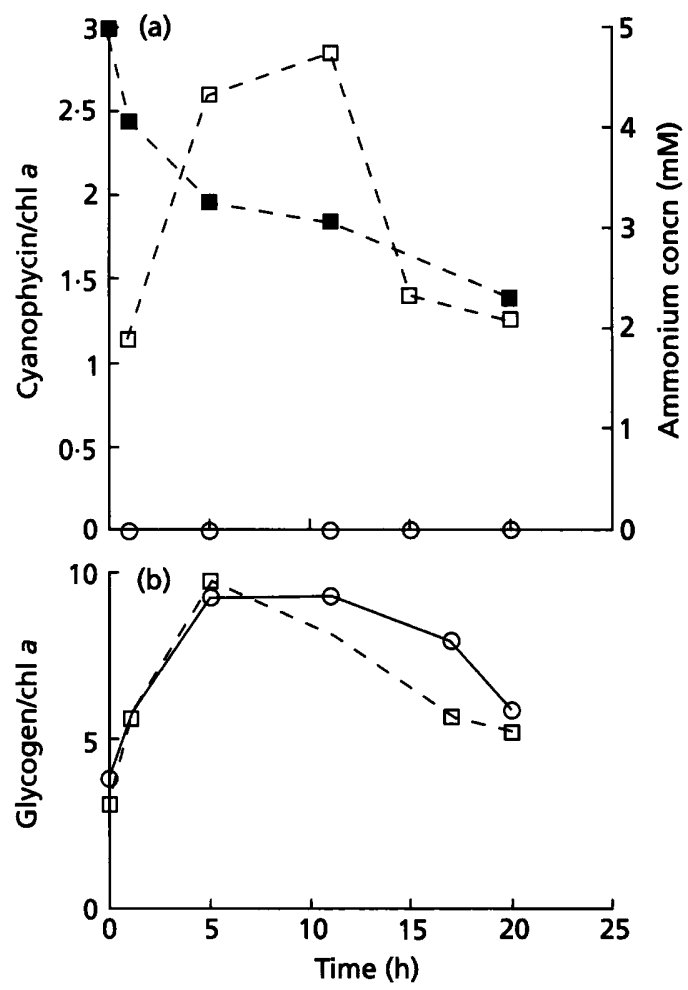

Fig. 3. Time-course experiment showing the accumulation of cyanophycin (a) and glycogen reserves (b) in nitrate- and ammonium-grown cells of Calothrix PCC 7601, and consumption of ammonium in the culture medium (a). Cyanophycin and glycogen in nitrate- (-O-) or ammoniumgrown cells (--- $\square---)$ are expressed as $\mu \mathrm{g}$ per $\mu \mathrm{g}$ chlorophyll a (chl a), and ammonium concentration remaining in the culture medium (--- ---) in $\mathrm{mM}$. After $26 \mathrm{~h}$ growth in the presence of ammonium, cells no longer contained any cyanophycin granules (data not shown).

rapid glycogen accumulation, at the same rate [approximately 1.2 $\mu \mathrm{g}$ glycogen $(\mu \mathrm{g} \mathrm{chl} a)^{-1} \mathrm{~h}^{-1}$ ] irrespective of the nitrogen source. The glycogen content of the cells was 2.5-3 times higher at $5 \mathrm{~h}$ than at $0 \mathrm{~h}$ and represented approximately $17 \%$ of the dry weight. After $5 \mathrm{~h}$, the rate of glycogen accumulation decreased under both growth conditions but remained slightly higher in nitrate-grown cells. As the net increase in glycogen became smaller than that of chlorophyll $a$, the specific glycogen content of the cells decreased in both ammonium- and nitrate-grown cells and at $20 \mathrm{~h}$ resulted in levels similar to those observed at the onset of the experiment.

Thus, transient increases in cyanophycin granule polypeptides and glycogen occurred under the same standard conditions that led to stable phycobiliprotein levels.

\section{Effect of nitrate and ammonium on phycobiliprotein transcripts}

To investigate the molecular basis for the difference in phycobiliprotein synthesis during cell growth in the presence of either ammonium or nitrate, we performed RNA/DNA hybridizations. Quantifications of transcript levels were made by scanning radioactivity of the RNA blots presented in Fig. 4(a) and normalizing the signals to the $r n p B$ transcripts in each lane. During the first hour following the transfer of the cells to experimental culture conditions, the steady-state levels of the transcripts corresponding to the $a p c 1, c p c 1, c p c 2$ and $c p e B A$ operons decreased to different extents in ammonium-grown cells (Fig. 4b). In nitrate-grown cells, this decrease was less pronounced for the $c p c 1$ and $c p e B A$ transcripts; in contrast, the $c p c 2$ and $a p c 1$ transcripts remained about constant. After a rapid increase of all transcripts to reach a maximum level between $5 \mathrm{~h}$ and $11 \mathrm{~h}$, their abundance subsequently declined to a level close to that observed at $0 \mathrm{~h}$. These transient changes in the abundance of the mRNAs at different times during cell growth were neither accompanied by nor followed by significant change in the amounts of the corresponding gene products (Fig. $2 \mathrm{a}-\mathrm{c}$ ).

Fig. 4(c) expresses the relative abundance of each phycobiliprotein transcript as the ratio of that observed in ammonium- to that of nitrate-grown cells. There were slightly fewer apc1 transcripts under the former conditions. The ratios of $c p c 1$ transcripts decreased during the first hour following the transfer to a fresh medium but then returned to about a mean value of $1 \cdot 25$, similar to the level at zero time. The ratios of the $c p c 2 \mathrm{mRNAs}$ were more variable, but the mean value was higher than those obtained for the $c p c 1$ transcripts. In contrast to $c p c 2$, there were fewer $c p e B A$ mRNAs in ammonium- than in nitrategrown cells. These plots, together with those presented in Fig. 4(b), demonstrate the opposing effects of the two nitrogen sources on the abundance of the $c p c 2$ and $c p e B A$ transcripts, and also reveal that the $c p c 1$ and $a p c 1$ transcripts are less affected. The overall differences in mRNA abundances under the two nitrogen regimes are in good agreement with the spectroscopic data obtained for the corresponding gene products PE and PCs (PC-1 and PC-2) (Fig. 2a, b). In the case of apc1, the corresponding gene product $A P$ was the same under both nitrogen conditions (Fig. 2c) despite the $20 \%$ difference in transcript abundance.

Primer extension experiments were performed with RNA isolated from nitrate- and ammonium-grown cells to test whether variations in the relative abundance of the $c p e B A$ and the $c p c 2 \mathrm{mRNAs}$ reflected different uses of specific transcription start sites under the two regimes of fixed nitrogen. Results showed that transcription started at the same site for the $c p e B A$ and the $c p c 2$ operons irrespective of the nitrogen source provided for cell growth (Fig. 5a). A primer complementary to nucleotides at position 144-163 upstream from the first initiation codon of the $c p c B 2$ gene generated a single extension product (Fig. 5a and $\mathrm{P} 1$ in Fig. 5b), while a primer located at nucleotides 48-29 revealed three additional minor products (P2, P3 and P4 in Fig. 5b). All these transcription start sites were identical to those obtained for the $c p e B A$ and the $c p c 2$ operons with cells grown under green and red light, respectively (data not shown). 


\section{DISCUSSION}

In the present work, we show that the nitrogen source specifically alters the phycobiliprotein content of Calotbrix PCC 7601 cells. PE and PC levels vary in opposite directions, the former being lower in ammonium- than in nitrate-grown cells and the latter higher under the same conditions. The overall phycobilisome number and rod length remain, however, similar in nitrate- and ammonium-grown cells, with only the specific composition of the rods being modified. Considering that a PE monomer carries five tetrapyrrole chromophores and a PC monomer only three (Glazer, 1989), it can be estimated that at least $10 \%$ fewer chromophores are required to build up phycobilisomes in ammonium- than in nitrategrown cells. As phycobiliproteins represent approximately $25 \%$ of the total cell protein under the present experimental conditions, this would correspond to a substantial economy in the use of glutamate molecules, the substrate of the first enzyme involved in the synthesis of tetrapyrrole chromophores in cyanobacteria (Beale, 1994). The benefits of such an economy are not readily evident. One could postulate, however, that the changes in phycobiliprotein and chromophore content are a means of adjusting the photosynthetic activity, in such a way that the production of reducing power does not exceed its demand, which is expected to be lower in ammoniumthan in nitrate-grown cells.

Our results provide quantitative data confirming the work of Erokhina (1992), who observed, for a few cyanobacteria, changes in the absorption spectra of cells and phycobilisomes by varying the source of fixed nitrogen. In Synecbococcus sp. strain PCC 7002, which is not a PE-containing cyanobacterium, de Lorimier et al. (1992) found that phycobilisomes isolated from ammoniumgrown cultures consistently contained $10-20 \%$ more phycocyanin than those grown with nitrate. In Calotbrix PCC 7601, we did not observe any significant difference in the total phycobiliprotein content between ammoniumand nitrate-grown cells, as there is a compensation due to a modulation of the syntheses of PC and PE in opposite directions. This modulation might concern PE-containing strains in general or be specific only for those able to undergo complementary chromatic adaptation.

Calothrix PCC 7601 cells transiently accumulate cyanophycin granule polypeptide when grown in the presence of ammonium. Accumulation and disappearance of this nitrogen reserve are correlated with the rapid decline of ammonium concentration in the culture medium during growth, but not with the effect of ammonium on phycobiliproteins, since cyanophycin reaches a maximum and then disappears without noticeable changes in the synthesis of these chromoproteins. Cyanophycin storage could not, however, be the unique means to avoid intracellular ammonium toxicity as cyanophycin represented, on a $\mathrm{N}$ atom basis, at most $5 \%$ of the ammonium consumed from the culture medium. When the ammonium uptake slows, the specific rate of cyanophycin granule polypeptide synthesis declines. These reserves are then mobilized, since after a decrease in the net cell content from $11 \mathrm{~h}$ after transfer, their steady-state level returns to zero by $26 \mathrm{~h}$. This accumulation and decrease of cyanophycin granule polypeptide may well be due to threshold effects of the external concentration of ammonium during growth. However, the experiments were initiated with a dilution of the cultures; therefore other factors might be involved, such as increased light irradiance, replenishment of a minor constituent of the medium or dilution of a substance that accumulated during growth.

Cyanobacteria generally accumulate cyanophycin granule polypeptide as a reserve compound during the transition from exponential to stationary phase (Simon, 1973b; Allen et al., 1980). These polypeptides can also be synthesized immediately following the addition of a usable source of fixed nitrogen to nitrogen-starved cells (Rippka \& Stanier, 1978; Allen \& Hutchison, 1980) or, as in Anabaena cylindrica, following addition of ammonium to cells previously acclimated to $\mathrm{N}_{2}$-fixing conditions (Mackerras et al., 1990). As in A. cylindrica, the accumulation of cyanophycin granules in Calotbrix PCC 7601 was rapid and transient, and occurred in nitrogen-replete cells, since the preculture still contained $2.0 \mathrm{mM}$ ammonium at the time of transfer to fresh medium. Cells grown on nitrate did not, however, contain cyanophycin granule polypeptide at any phase of growth. The levels of nitrate and nitrite reductase activities (or syntheses) might thus be too low to produce ammonium in amounts sufficient to stimulate the enzymes involved in arginine and aspartate syntheses. In A. cylindrica cells, for example, the high concentration of glutamine resulting from the assimilation of exogenously supplied ammonium indeed favours arginine synthesis, via the carbamoyl phosphatecitrulline pathway (Ohmori \& Ohmori, 1990). Furthermore, a glutamate-aspartate aminotransferase activity can drive the formation of aspartate after incorporation of $\mathrm{NH}_{4}^{+}$into glutamine and glutamate (Flores \& Herrero, 1994). Arginine and aspartate thus synthesized can then polymerize to form cyanophycin granule polypeptides. If such enzymic pathways prove to function similarly in Calothrix PCC 7601 cells, they could contribute to the high production of cyanophycin granule polypeptides specifically in ammonium- and not in nitrate-grown cells.

Mackerras et al. (1990) suggested that the carbon skeletons for cyanophycin synthesis may originate from the degradation of glycogen following addition of nitrogen to starved cells. In Calothrix PCC 7601 cells grown under the present conditions, however, accumulation of cyanophycin granule polypeptide occurred concomitantly with an accumulation of glycogen. Indeed, the net glycogen content of the cells reached a maximum shortly after inoculation into fresh culture media and then decreased, with only a slight difference between ammonium- and nitrate-grown cells. This initial rapid glycogen storage probably resulted from an enhancement of photosynthetic activity due to an increase of light irradiance upon dilution of the cultures. Sudden changes in irradiance may affect the carbon/nitrogen ratio and induce glycogen accumulation in cyanobacterial cells irrespective of the nitrogen 
(a)

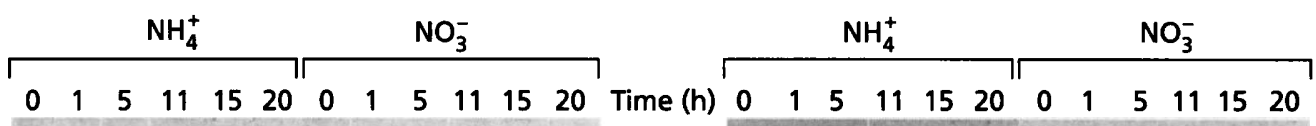
apcA1B1

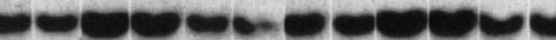

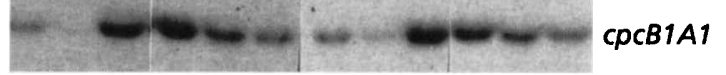

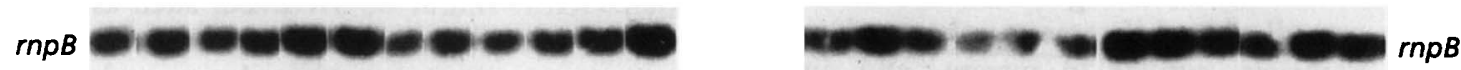

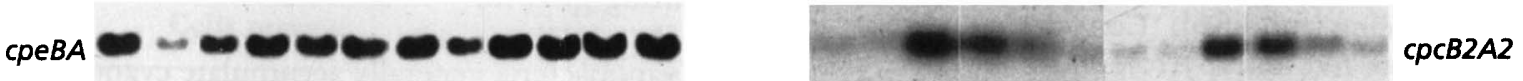

(b)
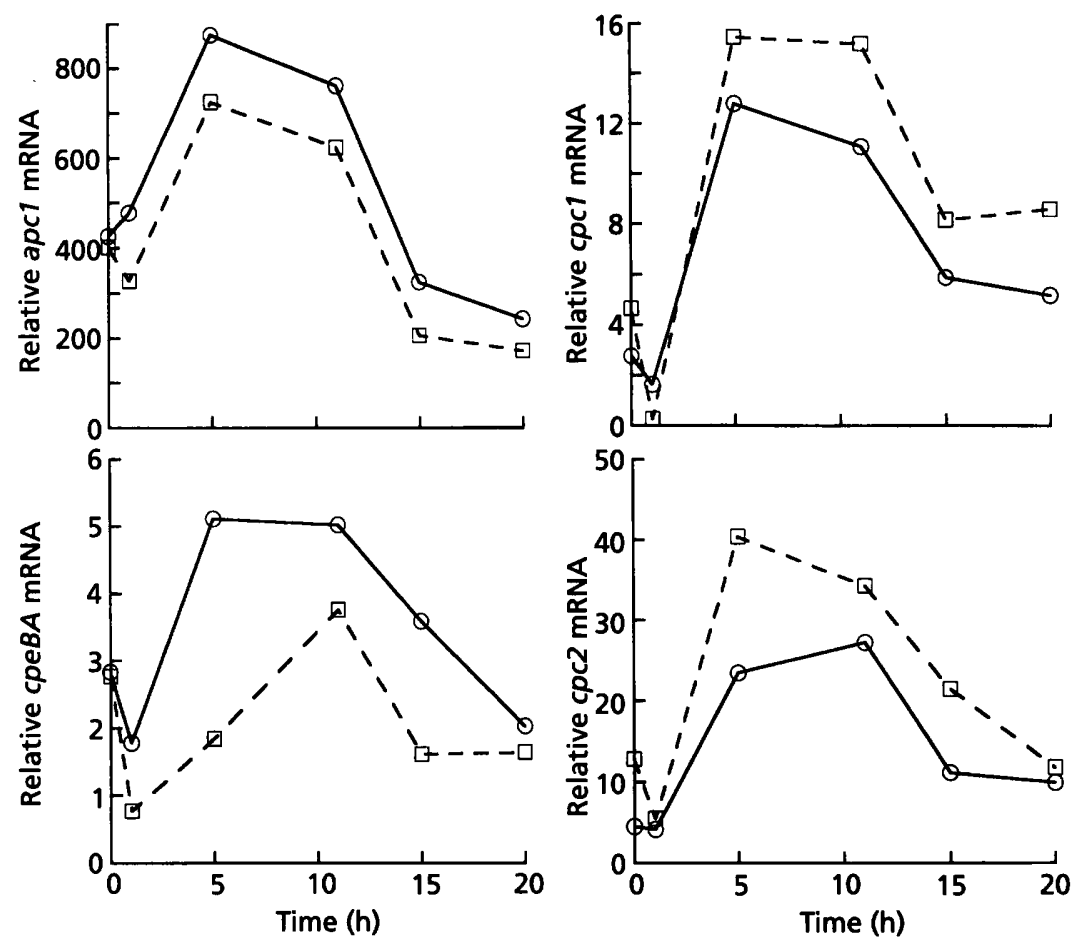

(c)
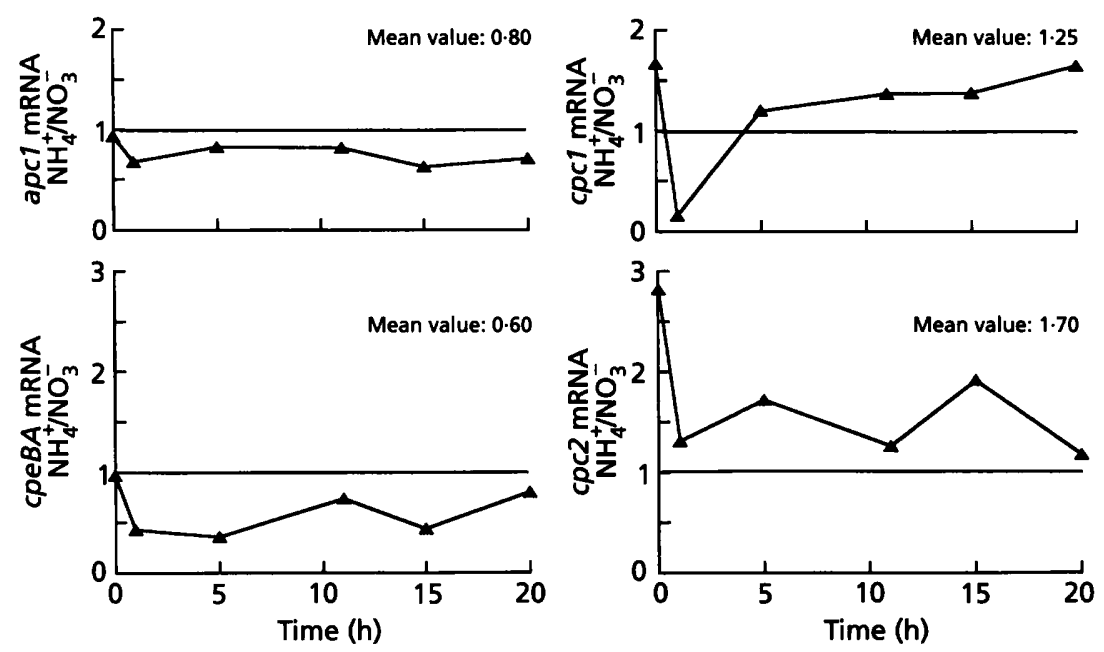

Fig. 4. (a) RNA blot analysis of the apcA1B1, cpcB1A1, cpeBA, $c p c B 2 A 2$ and rnpB transcripts from Calothrix PCC 7601 cells grown in nitrate or ammonium. The sizes (in kb) of the transcripts encoding $\alpha$ and $\beta$ subunits of phycobiliproteins are: 1.4 for apcA1B1, 1.6 for $C p C B 1 A 1$ and $C P C B 2 A 2$, and 1.5 for $c p e B A$. The minor larger mRNA species corresponding to the 
(a)
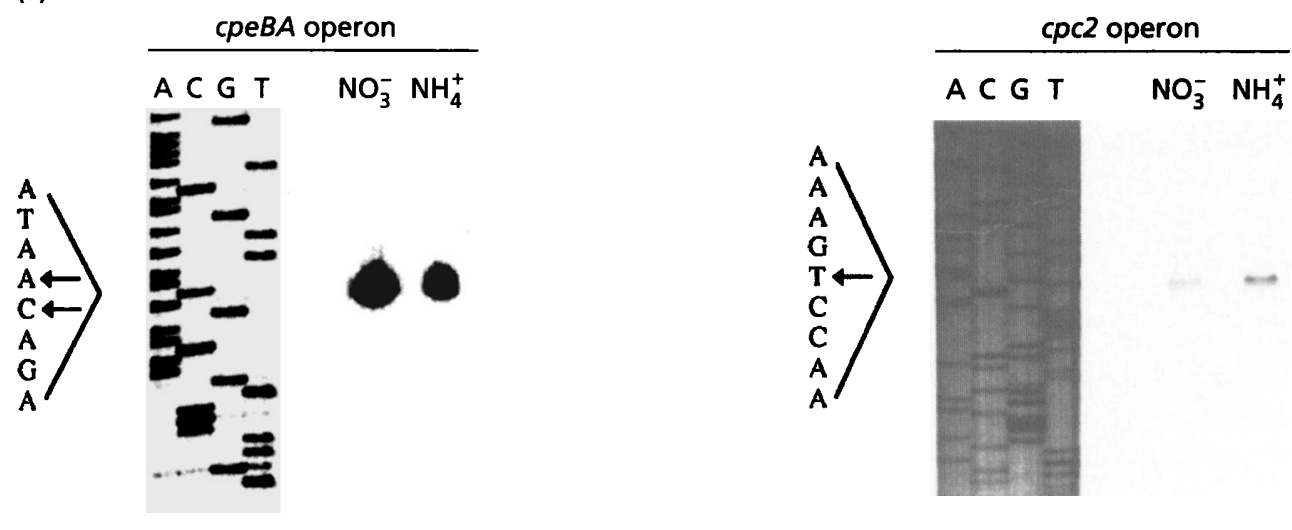

(b)

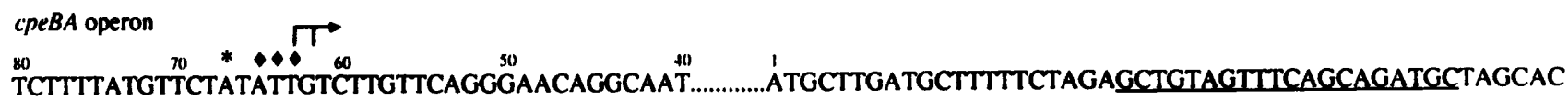

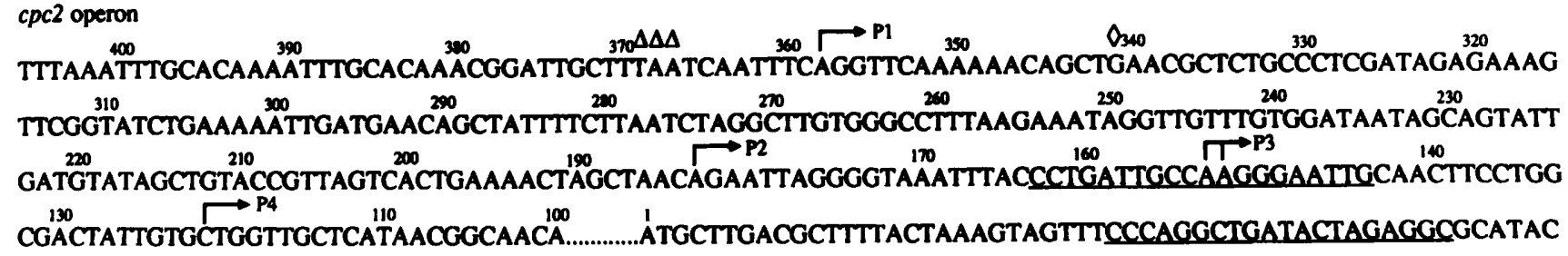

Fig. 5. (a) Primer extension analysis of the cpeBA and $c p c 2$ mRNAs in Calothrix PCC 7601 cells grown in nitrate or in ammonium. The sequencing ladder (complementary to the sense strand) was generated by using the same primer as that employed for the extension reactions. Transcription start points are indicated on the left-hand side by arrows. (b) Nucleotide sequence (sense strand) of the promoter regions of the cpeBA and cpc2 operons. Nucleotides are numbered with respect to the initiation codons. The different transcription start sites determined in different laboratories are indicated as follows. For the cpeBA operon: $\diamond$, Federspiel \& Grossman (1990); *, Tandeau de Marsac et al. (1988); arrows, this study. For the cpc2 operon: $\triangle$. Conley et al. (1988); $\diamond, V$. Capuano \& J. Houmard, unpublished data and Sobczyk et al. (1994); arrows, this study. The oligonucleotides used as primers were complementary to the underlined nucleotide sequences.

source (Ernst et al., 1984; Ernst \& Böger, 1985; De Philippis $e$ t al., 1992). In contrast, the subsequent decrease in the net cellular glycogen content might depend on the nitrogen source. In Anacystis nidulans (Synechococcus sp. PCC 6301), nitrogen assimilation can affect the rate of $\mathrm{CO}_{2}$ fixation, decreasing incorporation of carbon into carbohydrates and enhancing carbon flow to organic and amino acids at the expense of the glycogen reserve. These effects are even more pronounced in the presence of ammonium than with nitrate (Romero \& Lara, 1987; García-González et al., 1992; Coronil et al., 1993). Such a control seems to occur in Calotbrix PCC 7601 and predominates in the later phase of the exponential growth of cells in the presence of ammonium. The decrease of glycogen accumulation occurred over a time period when cyanophycin granule polypeptide synthesis ceased. These phenomena may be related, as an enhanced incorporation of carbon into compounds other than glycogen may occur in response to an increased intracellular nitrogen content corresponding to cyanophycin disappearance.

transcription of the entire apc1 and $c p c 2$ operons are not presented. The prints of the autoradiograms corresponding to the hybridizations with the apcA1B1 and $c p e B A$ (left-hand side) and $c p c B 1 A 1$ and $c P C B 2 A 2$ (right-hand side) DNA probes were cut and assembled together for convenience. Middle panels: the same two RNA blots were hybridized with a DNA probe of the Calothrix PCC 7601 rnpB gene to provide an estimate of the RNA loading. The rnpB transcript is about $0.5 \mathrm{~kb}$. (b) Time course of the variation in the transcript levels of the apcA1, cpc1, cpeBA and cpc2 operons in nitrate$(-\mathrm{O} \rightarrow$ ) or ammonium-grown cells (--- $\square---)$. Values relative to the rnpB trancript level were obtained after scanning of the RNA biots and correspond to the sum of all the transcripts for each of the operons, of which only the major transcripts are presented in (a). (c) Changes in the transcript levels of the apcA1, cpc1, cpeBA and cpc2 operons in response to the nitrogen source. The plots show the ratios of transcripts in ammonium-grown cells to those of nitrategrown cells (values of transcript levels determined as in b). 
The effect of ammonium on the synthesis of phycobiliproteins resembles to some degree the red-light effect observed during complementary chromatic adaptation. In Calotbrix PCC 7601, the regulation of the expression of the $c p e B A$ and $c p c 2$ operons under green and red light, respectively, operates mainly at the transcriptional level, and involves specific DNA-binding proteins that recognize the promoter regions (Tandeau de Marsac \& Houmard, 1993; Sobczyk et al., 1993, 1994). The present study shows that the regulation by the nitrogen source also operates at least in part at the mRNA level, with fewer $c p e B A$ and more $c p c 2$ transcripts in ammoniumthan in nitrate-grown cells. The transcript abundance of the $c p c 1$ genes was also somewhat higher in ammoniumgrown cells. A similar effect has been described in complementary chromatic adaptation, with a slightly greater level of $c p c 1 \mathrm{mRNAs}$ in red- than in green-lightgrown cells (Conley et al., 1986). In the case of the apc1 operon the difference in the transcript levels, which is not correlated with a change in the AP content between nitrate- and ammonium-grown cells, is more questionable as it represents approximately $20 \%$, a value which could be within the experimental errors intrinsic to such quantifications. If this difference is significant, however, it would indicate a post-transcriptional regulation of the expression of the apc1 operon.

Although a slow turnover of the phycobiliproteins cannot be excluded, a post-transcriptional regulation might also occur for the expression of the other phycobiliprotein operons, as the transient changes in transcript abundance observed during growth do not affect the level of the corresponding proteins. A stress effect resulting from cell dilution could explain the decrease in transcript abundance $1 \mathrm{~h}$ after transfer of the cells to a fresh medium, which was probably too brief to be reflected in phycobiliprotein cell content. In contrast to this stress effect seen with both nitrogen sources, there is a specific effect of ammonium on transcription and synthesis of phycobiliproteins, maintained over at least three cell generations too long for a stress effect to persist.

The transcription start sites determined for the $c p e B A$ and $c p c 2$ operons, in nitrate- or ammonium-grown cells, are the same as those identified for the cpeB $A$ and $c p c 2$ operons in green- and red-light-grown cells, respectively. Fig. 5(b) shows a comparison of the transcription start sites determined in the present work with those already published. The transcription start sites identified for the cpe $B A$ operon are very close to those previously found. The P1 transcription start site for the $c p c 2$ operon is located a few nucleotides from the transcription start sites found for the $c p c 2$ operon in red-light-grown cells. The size of the mRNA expected from this transcription start site corresponded to that of the transcript revealed by RNA/DNA hybridization. Three additional minor extension products (P2, P3 and P4) were also detected which were not identified by previous S1 mapping experiments and did not correspond to any stable full-length mRNAs after hybridization of the RNA blots with DNA probes from the $c p c 2$ operon. These additional products might in fact be due to the presence of mRNA secondary structures to which the technique of primer extension is more sensitive than is $\mathrm{S} 1$ mapping.

Previous studies with strains of Calothrix sp. have shown that: (i) both the intensity and the spectral quality of the light affect phycobiliprotein synthesis; and (ii) both the spectral light quality and the nitrogen supply can control cell differentiation processes, such as those of heterocysts and hormogonia (Campbell et al., 1993; Campbell, 1994). The similar specific effects of fixed nitrogen source and light spectral quality on phycobiliprotein synthesis presented in this report support the idea that there are common regulatory mechanisms, or at least cross-talk, between nitrogen assimilation and complementary chromatic adaptation to control phycobiliprotein gene expression and thus optimize the collection of light energy for balancedcellgrowth. Ourresultsprovidenew cluestounderstanding these interactions between nitrogen assimilation, photosynthesis and cell differentiation in Calotbrix PCC 7601.

\section{ACKNOWLEDGEMENTS}

We wish to thank M. Herdman for helpful discussions and critical reading of the manuscript, M. M. Allen for advice for determination of cyanophycin granule polypeptides, B. Brahamsha for communicating the primer extension technique and $A$. Vioque for the $r m p B$ gene. We also acknowledge K. Forchhammer and J. Meeks for helpful discussions. S. L. received a fellowship from the Ministère de l'Enseignement Supérieur et de la Recherche. D.C. received a post-doctoral fellowship from the Natural Sciences and Engineering Research Council of Canada. This work was supported by the Institut Pasteur and the Centre National de la Recherche Scientifique (URA 1129).

\section{REFERENCES}

Abeliovich, A. \& Azov, Y. (1976). Toxicity of ammonia to algae in sewage oxidation ponds. Appl Environ Microbiol 31, 801-806.

Allen, M. M. (1984). Cyanobacterial cell inclusions. Annu Rev Microbiol 38, 1-25.

Allen, M. M. \& Hutchison, F. (1980). Nitrogen limitation and recovery in the cyanobacterium Aphanocapsa 6308. Arch Microbiol 128, 1-7.

Allen, M. M. \& Smith, A. J. (1969). Nitrogen chlorosis in bluegreen algae. Arch Mikrobiol 69, 114-120.

Allen, M. M. \& Weathers, P. J. (1980). Structure and composition of cyanophycin granules in the cyanobacterium Aphanocapsa 6308. $J$ Bacteriol 141, 959-962.

Allen, M. M., Hutchison, F. \& Weathers, P. J. (1980). Cyanophycin granule polypeptide formation and degradation in the cyanobacterium Aphanocapsa 6308. J Bacteriol 141, 687-693.

Beale, S. I. (1994). Biosynthesis of cyanobacterial tetrapyrrole pigments: hemes, chlorophylls, and phycobilins. In The Molecular Biology of Cyanobacteria, pp. 519-558. Edited by D. A. Bryant. Dordrecht: Kluwer.

Boussiba, S. \& Gibson, J. (1991). Ammonia translocation in cyanobacteria. FEMS Microbiol Rev 88, 1-14.

Boussiba, S. \& Richmond, A. E. (1980). C-phycocyanin as a storage protein in the blue-green alga Spirulina platensis. Arch Microbiol 125, 143-147.

Boussiba, S., Resch, C. M. \& Gibson, J. (1984). Ammonia uptake and retention in some cyanobacteria. Arch Microbiol 138, 287-292. 
Bryant, D. A. (1987). The cyanobacterial photosynthetic apparatus: comparison of those of higher plants and photosynthetic bacteria. In Photosynthetic Picoplankton (Can Bull Fish Aquat Sci 214), pp. 423-500. Edited by T. Platt \& W. K. W Li.

Bryant, D. A. (1991). Cyanobacterial phycobilisomes: progress toward complete structural and functional analysis via molecular genetics. In Cell Culture and Somatic Cell Genetics of Plants, vol. 7B, The Photosynthetic Apparatus: Molecular Biology and Operation, pp. 257-300. Edited by L. Bogorad \& I. K. Vasil. New York: Academic Press.

Bryant, D. A. \& Cohen-Bazire, G. (1981). Effects of chromatic illumination on cyanobacterial phycobilisomes. Evidence for the specific induction of a second pair of phycocyanin subunits in Pseudanabaena 7409 grown in red light. Eur J Biochem 119, 415-424.

Campbell, D. (1994). Relations entre l'environnement, le métabolisme intermédiaire et la différenciation cellulaire chez une cyanobactérie filamenteuse. Bull Inst Pasteur 92, 27-43.

Campbell, D., Houmard, J. \& Tandeau de Marsac, N. (1993). Electron transport regulates cellular differentiation in the filamentous cyanobacterium Calotbrix. Plant Cell 5, 451-463.

Carr, N. G. (1988). Nitrogen reserves and dynamic reservoirs in cyanobacteria. In Biochemistry of the Algae and Cyanobacteria (Annual Proceedings of the Phytochemical Society of Europe), pp. 13-21. Edited by L. J. Rogers \& J. R. Gallon. Oxford: Clarendon Press.

Collier, J.L. \& Grossman, A. R. (1992). Chlorosis induced by nutrient deprivation in Synecbococcus sp. strain PCC 7942: not all bleaching is the same. J Bacteriol 174, 4718-4726.

Collier, J. L. \& Grossman, A. R. (1994). A small polypeptide triggers complete degradation of light-harvesting phycobiliproteins in nutrient-deprived cyanobacteria. EMBO J 13, 1039-1047.

Conley, P. B., Lemaux, P. G., Lomax, T. L. \& Grossman, A. R. (1986). Genes encoding major light-harvesting polypeptides are clustered on the genome of the cyanobacterium Fremyella diplosiphon. Proc Natl Acad Sci US A 83, 3924-3928.

Conley, P. B., Lemaux, P. G. \& Grossman, A. (1988). Molecular characterization and evolution of sequences encoding light-harvesting components in the chromatically adapting cyanobacterium Fremyella diplosiphon. J Mol Biol 199, 447-465.

Coronil, T., Lara, C. \& Guerrero, M. G. (1993). Shift in carbon flow and stimulation of amino-acid turnover induced by nitrate and ammonium assimilation in Anacystis nidulans. Planta 189, 461-467.

De Lorimier, R. M., Smith, R. L. \& Stevens, S. E., Jr (1992). Regulation of phycobilisome structure and gene expression by light intensity. Plant Physiol 98, 1003-1010.

De Philippis, R., Sili, C. \& Vincenzini, M. (1992). Glycogen and poly- $\beta$-hydroxybutyrate synthesis in Spirulina maxima. J Gen Microbiol 138, 1623-1628.

Ernst, A. \& Boger, P. (1985). Glycogen accumulation and the induction of nitrogenase activity in the heterocyst-forming cyanobacterium Anabaena variabilis. J Gen Microbiol 131, 3147-3153.

Ernst, A., Kirschenlohr, H., Diez, J. \& Bø̈ger, P. (1984). Glycogen content and nitrogenase activity in Anabaena variabilis. Arcb Microbiol 140, 120-125.

Erokhina, L. G. (1992). Spectral effects of chromatic adaptation of nitrogen-fixing cyanobacteria growing on different nitrogen sources. Microbiology (English translation of Mikrobiologiya) 61, 673-679.

van Eykelenburg, C. (1980). Ecophysiological studies on Spirulina platensis. Effect of temperature, light intensity and nitrate concentration on growth and ultrastructure. Antonie Leeuvenboek 46, 113-127.
Fay, P. (1992). Oxygen relations of nitrogen fixation in cyanobacteria. Microbiol Rev 56, 340-373.

Federspiel, N. A. \& Grossman, A. R. (1990). Characterization of the light-regulated operon encoding the phycoerythrin-associated linker proteins from the cyanobacterium Fremyella diplosiphon. $J$ Bacteriol 172, 4072-4081.

Flores, E. \& Herrero, A. (1994). Assimilatory nitrogen metabolism and its regulation. In The Molecular Biology of Cyanobacteria, pp. 487-517. Edited by D. A. Bryant. Dordrecht: Kluwer.

Garcla-González, M., Sivak, M. N., Guerrero, M. G., Preiss, J. \& Lara C. (1992). Depression of carbon flow to the glycogen pool induced by nitrogen assimilation in intact cells of Anacystis nidulans. Physiol Plant 86, 360-364.

Glazer, A. N. (1989). Light guides: directional energy transfer in a photosynthetic antenna. J Biol Chem 264, 1-4.

Golden, S. S., Brusslan, J. \& Haselkorn, R. (1986). Expression of a family of $p s b A$ genes encoding a photosystem II polypeptide in the cyanobacterium Anacystis nidulans R2. EMBO J 5, 2789-2798.

Grossman, A. R., Schaefer, M., Chiang, G. G. \& Collier, J. L. (1993). The phycobilisome, a light-harvesting complex responsive to environmental conditions. Microbiol Rev 57, 725-749.

Guerrero, M. G. \& Lara, C. (1987). Assimilation of inorganic nitrogen. In The Cyanobacteria, pp. 163-186. Edited by P. Fay \& C. Van Baalen. Amsterdam: Elsevier.

Houmard, J., Capuano, V., Coursin, T. \& Tandeau de Marsac, N. (1988). Genes encoding core components of the phycobilisome in the cyanobacterium Calotbrix sp. strain PCC 7601: occurrence of a multigene family. $J$ Bacteriol 170, 5512-5521.

Kallas, T., Coursin, T. \& Rippka, R. (1985). Different organization of nif genes in nonheterocystous and heterocystous cyanobacteria. Plant Mol Biol 5, 321-329.

Lawry, N. H. \& Simon, R. D. (1982). The normal and induced occurrence of cyanophycin inclusion bodies in several blue-green algae. J Pbycol 18, 391-399.

Lehmann, M. \& Wobber, G. (1976). Accumulation, mobilization and turn-over of glycogen in the blue-green bacterium Anacystis nidulans. Arch Microbiol 111, 93-97.

Mackerras, A. H., de Chazal, N. M. \& Smith, G. D. (1990). Transient accumulations of cyanophycin in Anabaena cylindrica and Synechocystis 6308. J Gen Microbiol 136, 2057-2065.

Martín-Nieto, J. , Herrero, A. \& Flores, E. (1989). Regulation of nitrate and nitrite reductases in dinitrogen-fixing cyanobacteria and Nif ${ }^{-}$mutants. Arch Microbiol 151, 475-478.

Mazel, D., Guglielmi, G., Houmard, J., Sidler, W., Bryant, D. A. \& Tandeau de Marsac, N. (1986). Green light induces transcription of the phycoerythrin operon in the cyanobacterium Calotbrix 7601. Nucleic Acids Res 14, 8279-8290.

Ohmori, M. \& Ohmori, K. (1990). Ammonium-nitrogen partitioning under different balances of nitrogen and carbon in the cyanobacterium Anabaena cylindrica. J Gen Appl Microbiol 36, 171-177.

Rippka, R. \& Stanier, R. Y. (1978). The effects of anaerobiosis on nitrogenase synthesis and heterocyst development by nostocacean cyanobacteria. J Gen Microbiol 105, 83-94.

Rippka, R., Deruelles, J., Waterbury, J. B., Herdman, M. \& Stanier, R. Y. (1979). Generic assignments, strain histories and properties of pure cultures of cyanobacteria. J Gen Microbiol 111, 1-61.

Romero, J. M. \& Lara, C. (1987). Photosynthetic assimilation of $\mathrm{NO}_{3}^{-}$by intact cells of the cyanobacterium Anacystis nidulans. Influence of $\mathrm{NO}_{3}^{-}$and $\mathrm{NH}_{4}^{+}$assimilation on $\mathrm{CO}_{2}$ fixation. Plant Physiol 83, 208-212. 
Schyns, G., Sobczyk, A., Tandeau de Marsac, N. \& Houmard, J. (1994). Specific initiation of transcription at a cyanobacterial promoter with RNA polymerase purified from Calothrix sp. PCC 7601. Mol Microbiol 13, 887-896.

Simon, R. D. (1971). Cyanophycin granules from the blue-green alga Anabaena cylindrica : a reserve material consisting of copolymers of aspartic acid and arginine. Proc Natl Acad Sci US A 68, 265-267.

Simon, R. D. (1973a). The effect of chloramphenicol on the production of cyanophycin granule polypeptide in the blue-green alga Anabaena cylindrica. Arch Mikrobiol 92, 115-122.

Simon, R. D. (1973b). Measurement of the cyanophycin granule polypeptide contained in the blue-green alga Anabaena cylindrica. $J$ Bacteriol 114, 1213-1216.

Simon, R. D. (1976). The biosynthesis of multi-L-arginyl-poly(Laspartic acid) in the filamentous cyanobacterium Anabaena cylindrica. Biochim Biopbys Acta 422, 407-418.

Smith, A. J. (1982). Modes of cyanobacterial carbon metabolism. In The Biology of Cyanobacteria (Botanical Monographs vol. 19), pp. 47-85. Edited by N. G. Carr \& B. A. Whitton. Oxford: Blackwell Scientific Publications.

Sobczyk, A., Schyns, G., Tandeau de Marsac, N. \& Houmard, J. (1993). Transduction of the light signal during complementary chromatic adaptation in the cyanobacterium Calothrix sp. PCC 7601 : DNA-binding proteins and modulation by phosphorylation. EMBO J 12, 997-1004.
Sobczyk, A., Bely, A., Tandeau de Marsac, N. \& Houmard, J. (1994). A phosphorylated DNA-binding protein is specific for the red-light signal during complementary chromatic adaptation in cyanobacteria. Mol Microbiol 13, 875-885.

Tandeau de Marsac, N. \& Houmard, J. (1988). Complementary chromatic adaptation: physiological conditions and action spectra. Methods Enzymol 167, 318-328.

Tandeau de Marsac, N. \& Houmard, J. (1993). Adaptation of cyanobacteria to environmental stimuli: new steps towards molecular mechanisms. FEMS Microbiol Rev 104, 119-190.

Tandeau de Marsac, N., Mazel, D., Damerval, T., Guglielmi, G., Capuano, V. \& Houmard, J. (1988). Photoregulation of gene expression in the filamentous cyanobacterium Calotbrix sp. PCC 7601 : light-harvesting complexes and cell differentiation. Photosynth Res 18, 99-132.

Vioque, A. (1992). Analysis of the gene encoding the RNA subunit of ribonuclease P from cyanobacteria. Nucleic Acids Res 20, 6331-6337.

Wyman, M., Gregory, R. P. F. \& Carr, N. G. (1985). Novel role for phycoerythrin in a marine cyanobacterium, Synecbococcus strain DC2. Science 230, 818-820.

Received 26 May 1995; revised 4 October 1995; accepted 2 November 1995. 